\title{
Conservation at Al-Areen Wildlife Park, Bahrain
}

Jaime Samour, James Irwin-Davies, Mubarak Mohanna and Essa Faraj

Bahrain was perhaps the first Arab country to realize the rapid decline of many native wild animal populations in the region and the urgent need to implement measures to ensure their survival. Part of Bahrain's response to this realization was the establishment of Al-Areen Wildlife Park. It was hoped that setting up a conservation centre dedicated to the preservation of wildlife would promote similar projects in other countries in the region. Now, more than 10 years since its creation, the authors review the original objectives of the project, its achievements and its aims for the future.

The independent state of Bahrain is an archipelago formed by 33 small desert islands situated midway along the Arabian shore in the
Arabian Gulf. Bahrain island, the largest, is located $32 \mathrm{~km}$ from the peninsula of Qatar to the east, $32 \mathrm{~km}$ from the coast of Saudi Arabia to

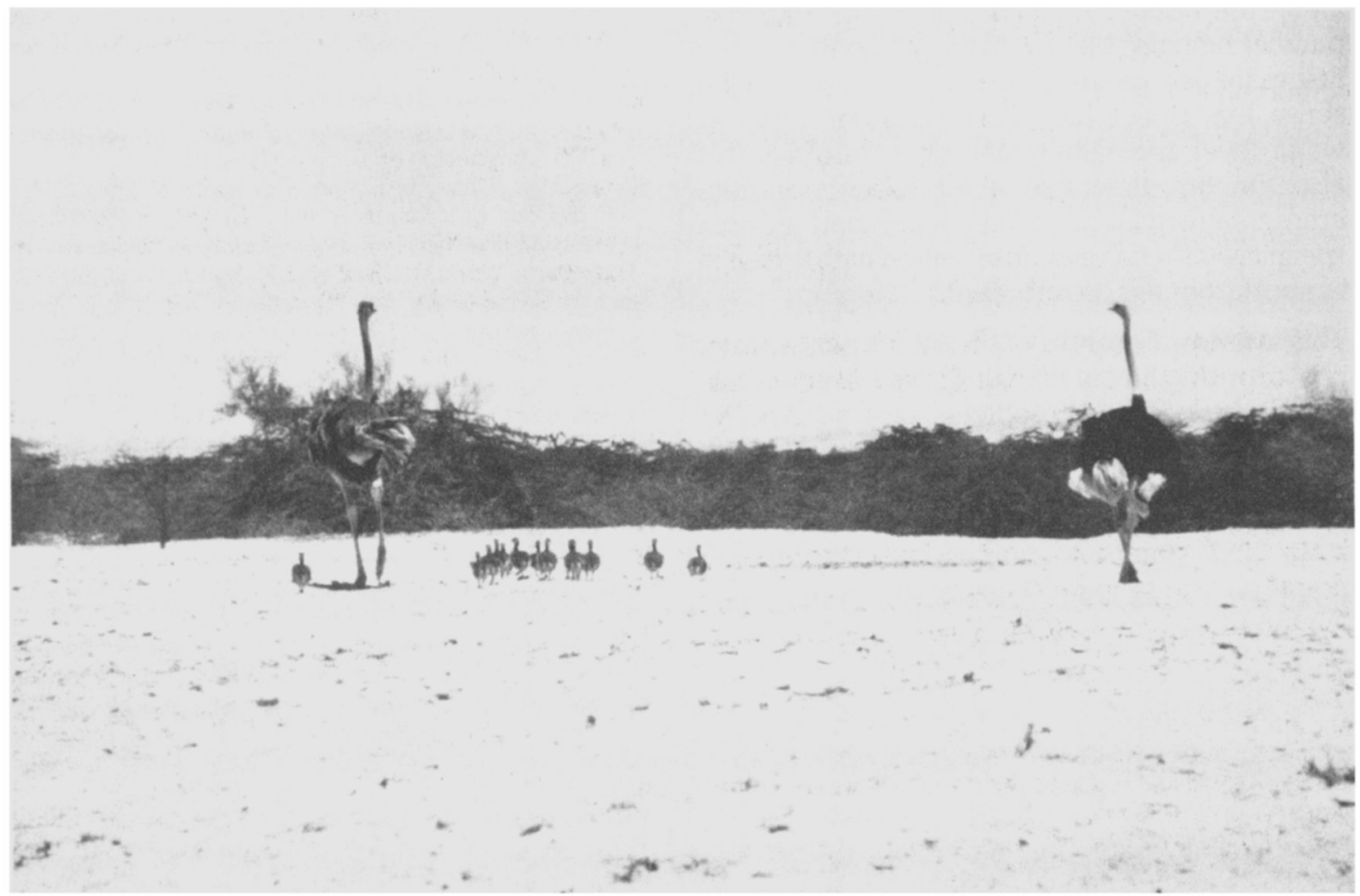


the west and $100 \mathrm{~km}$ from the Iranian coast to the north. The island, $48 \mathrm{~km}$ long and $16 \mathrm{~km}$ at its widest point, is a dome of Eocene limestone, most of which has eroded into large depressions surrounded by hills and cliffs up to $30 \mathrm{~m}$ high. The highest point of the remaining original dome is at $186 \mathrm{~m}$ at Jebel al Dukhan.

Al-Areen Wildlife Park was built between 1976 and 1979 at Al Markh, $5 \mathrm{~km}$ south-west of Jebel al Dukhan and $2 \mathrm{~km}$ from the Zallaq shoreline $\left(26^{\circ} 1^{\prime} \mathrm{N} 50^{\circ} 30^{\prime} \mathrm{E}\right.$ ) (Figure 1). The site is $2 \mathrm{~km} \times$ $4 \mathrm{~km}$, varying from salt flats about $3 \mathrm{~m}$ above sea level on the western side to about $45 \mathrm{~m}$ on the eastern side. The salt flats are mainly marinetype sand to barren salt. The highest point, known as the rimrock, is predominantly dolomite rock.

The average summer temperature is $38^{\circ} \mathrm{C}$ (min $26^{\circ} \mathrm{C}-\max 45^{\circ} \mathrm{C}$ ) and 40 per cent relative humidity. The average winter temperature is $16^{\circ} \mathrm{C}\left(\min 5^{\circ} \mathrm{C}-\max 22^{\circ} \mathrm{C}\right)$ and 80 per cent relative humidity. The average annual rainfall is $80 \mathrm{~mm}$, concentrated mainly between January and March. The prevailing wind is from the north-west.

The site selected was heavily grazed by camels and sheep from nearby farms. After the perimeter fence was erected, many species of native plants thrived, in particular Heliotropium tuberculosum, Fagonia indica, Lycium shavii and Leptadenia pyrotechnica. The original census of native fauna in the park included: more than 10 species of reptiles, in particular the spiny-tailed lizard Uromastyx microlepis and sand skink Scincus conirostris; at least three species of mammals, Bahraini hare Lepus capensis atallahi, Ethiopian hedgehog Paraechinus aethiopicus and the lesser three-toed jerboa Jaculatus jaculatus vocator; and four species of resident bird, the black-crowned finchlark Eremapterix nigriceps, desert lark Ammomanes deserti, crested lark Calerida cristata and the hoopoe lark Alaemon alaudipes.

To complement the existing vegetation, approximately 100,000 trees were planted, mainly Acacia sp., Atriplex sp., Parkinsonia sp. and Tamarix sp. These trees are irrigated using a trickle irrigation system, with water provided from three wells. This water has total dissolved Al-Areen Wildife Park, Bahrain solids (TDS) estimated at $3200 \mathrm{ppm}$. Now that the introduced vegetation is well established, and after the creation of artificial ponds, the number of resident birds has increased to approximately 15 species and more than 84 migrant species have been recorded at the site.

Al-Areen was developed primarily to provide a refuge for endangered species and as a wildlife educational centre. To accomplish this, the site was divided into two main sections, the park and the reserve. The park $(2 \mathrm{~km} \times 2 \mathrm{~km})$ is open to the public and contains a representative collection of ungulate species from the Arabian peninsula, East Africa, North Africa and Asia. There are nearly 500 individuals belonging to 30 species. There are also 60 species of birds from the same

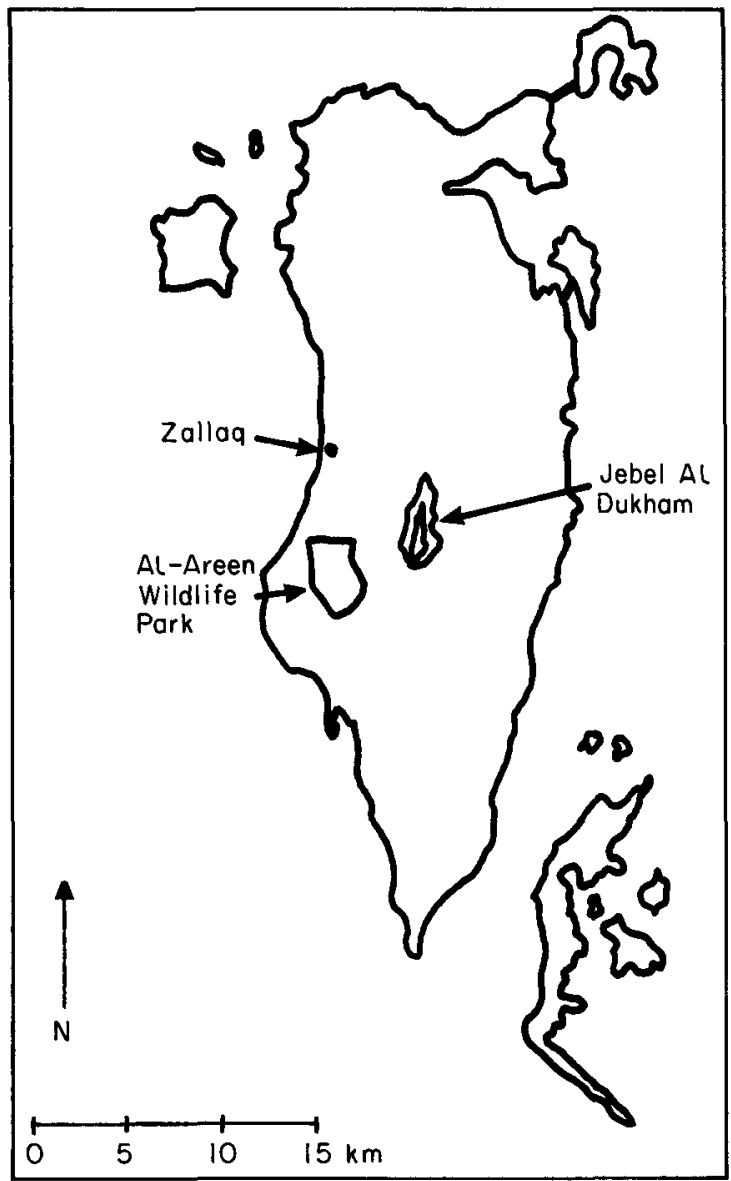

Figure 1. The location of Al-Areen Wildlife Park in Bahrain. 
areas, comprising nearly 450 individuals. Mammalian and avian species of particular interest are: wild sheep Ovis orientalis, scimitar-horned oryx Oryx dammah, addax Addaxnasomaculatus, dama gazelle Gazella dama, roan antelope Hippotragus equinus, demoiselle crane Anthropoides virgo, kori bustard Choriotis kori and ostrich Struthio camelus. Access to the reserve $(2 \mathrm{~km} \times 2 \mathrm{~km})$ is restricted. It contains only three species of mammals, Arabian or white oryx Oryx leucoryx, Nubian ibex Capra ibex nubiana and Saudi goitred gazelle Gazella subgutturosa marica, and two species of birds, houbara bustard Chlamydotis undulata and sooty falcon Falco concolor.

Al-Areen also has an important collection of Arabian and Asiatic gazelles. This collection is housed in a secluded compound and access is restricted. The species housed currently are: Saudi gazelle Gazella saudiva, Sudanese dorcas gazelle Gazella dorcas dorcas, chinkara gazelle Gazella bennetti, Persian goitred gazelle Gazella subgutturosa and Iraqui goitred gazelle, which is considered to be a race of the Persian goitred gazelle. The breeding programme currently under way for the Saudi gazelle, previously known as Saudi dorcas gazelle, is of particular interest, since this species is believed to be extinct in the wild and the group housed at Al-Areen is perhaps the only captive group in existence.

On arrival, visitors are shown a video illustrating the reasons behind the creation of Al-Areen, the animals housed and highlighting the importance of conservation in the area. Then, the public is allowed in the park through guided tours in specially equipped buses.

Al-Areen received international publicity in 1979 when $\mathrm{HH}$ The Crown Prince of Bahrain intervened in the rescue of a group of African antelope and zebra stranded at Rome airport. These animals were destined for a safari park but, because of alleged inadequate documentation, were not allowed into the country and many of them were dying within their confined quarters. The animals were flown to Bahrain and placed in Al-Areen, and were among the first few mammals housed at the park.

Al-Areen has also been deeply involved in conservation, not only by keeping and breeding en144 dangered species, but also by co-operating with other conservation projects in the region, particularly for Arabian oryx and houbara bustard. In this respect, male Arabian oryx from Al-Areen's herd have been sent to Jordan, Oman and Saudi Arabia in support of their breeding programmes.

At present, there are plans for a development programme that, if finalized, will place Al-Areen as the leading regional conservation institution and one of the most important conservation centres in the East. The first phase of the programme includes the acquisition of further ungulates and avian species from the Arabian zoogeographical region, which includes: North Africa, Jordan, Syria, Palestine, Iraq, Iran, Pakistan and the Arabian peninsula. Species of particular interest are Soemmerring's gazelle Gazella soemmerringi, slender-horned gazelle Gazella leptoceros, mountain gazelle Gazella gazella, Cuvier's gazelle Gazella cuvieri, Queen of Sheba's or Yemen gazelle Gazella bilkis, Arabian thar Hemitragus jayakari, northern bald ibis Geronticus eremita, Arabian bustard Ardeotis arabs, dalmatian pelican Pelecanus crispus and others. In the second phase the acquisition of other mammals is contemplated, for example, Arabian leopard Panthera pardus nimr, Arabian wolf Canis lupus arabs, Syrian wild ass Equus hemionus hemippus, small carnivores, and rodents. It is also hoped to acquire reptiles, amphibians, insects and fish. This change means that Al-Areen will become a specialist institution soley devoted to the conservation of endangered Arabian species, moving away from the concept of housing a representative collection of animals from different zoo-geographical zones.

A further step at Al-Areen is to pioneer research programmes on endangered ungulate and avian species in the field of reproductive physiology. For this purpose, a research facility has been set up, with strong links to the Zoological Society of London and the King Khalid Wildlife Research Centre at Tummammah in Saudi Arabia. One of the first projects will be the collection of semen from the Arabian and scimitar-horned oryx and to assess the efficacy of different diluents and cryopreservation protocols related to post-thaw spermatozoal survival. Frozen semen samples will be sent to the Zoological Society of London,

Oryx Vol 23 No 3, July 1989 
where they will be subjected to different in vitro fertility functional assays. Once a suitable cryopreservation method is found, the semen could be stored in a semen bank for any future work. The main objective of this exercise is to create a genetic rescue centre with frozen semen from endangered species for the future maintenance of genetic diversity in captive Arabian ungulate populations around the world.

Perhaps the best example for the application of this genetic rescue service in the near future is for the Arabian oryx in the World Herd in the US and other collections in European countries. After 25 years of the creation of the successful World Herd with just a handful of animals, the individuals from this population appear to differ in size and colouration to those still living in private collections throughout the Arabian countries. The shipment of frozen semen from selected specimens currently housed in Arab countries could be utilized for the re-introduction of original genetic material back to those in captive populations in America and Europe. This is a more viable proposition than the shipment of live animals, due to the international laws governing the import and export and the high cost of handling and transportation of live animals.

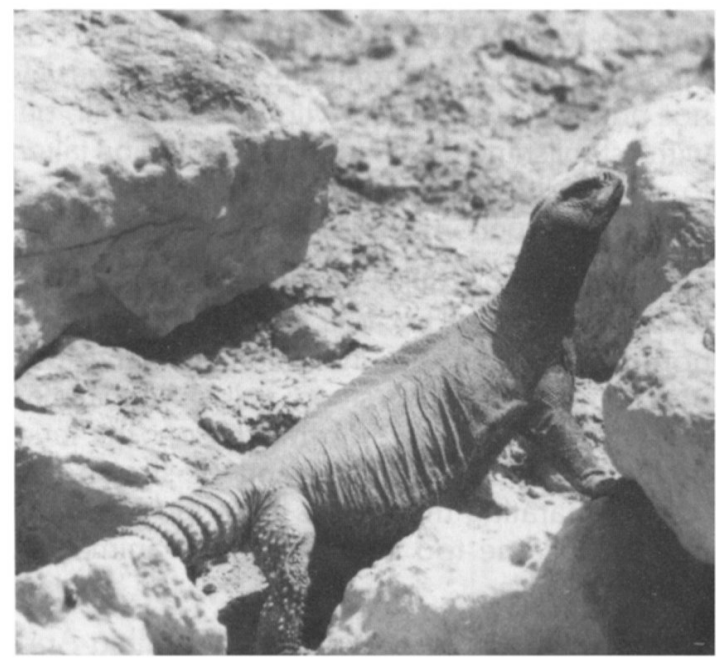

Spiny-tailed lizard (J. Samour)

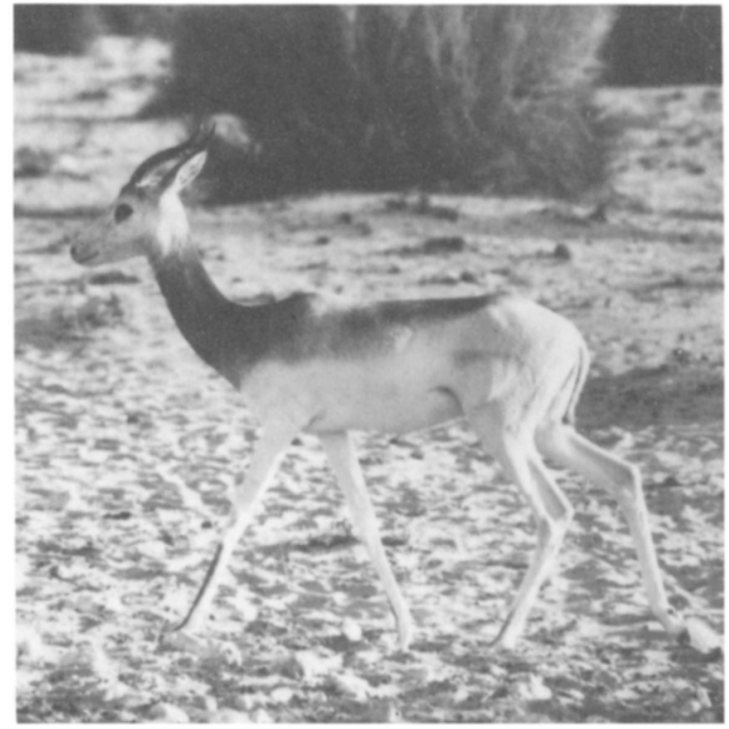

Female dama gazelle (J. Samour).

Historically, Arabs have had an intimate acquaintance with domesticated animals, which provided the basis of life for their nomadic existence. They were also well aware of the beneficial effects of protecting natural areas, or hemas, in which hunting and grazing were banned for a period of time and where use was restricted to a ruler or a tribe. Furthermore, in Islam a heavy responsibility is placed on man to guard and protect wild animals and their habitats, plainly expressed in art, literature and also depicted religiously in the Holy Qur'an. The creation of AlAreen and many other conservation projects throughout the Arab region was perhaps an attempt to revive the Islamic views of the interrelationship between man and his environment.

\section{Acknowledgments}

The authors would like to thank $\mathrm{HH}$ The Crown Prince Shaikh Hamad bin Essa Al-Khalifa, HE The Prime Minister Shaikh Khalifa bin Sulman Al-Khalifa and Shaikh Khalid bin Ahmed. Al-Khalifa for their interest in conservation and continuous support.

J. Samour, J. Irwin-Davies, M. Mohanna and E. Faraj, Al-Areen Wildlife Park, PO Box 28690, State of Bahrain, Arabian Gulf. 